\title{
Evaluasi Sifat Mekanik dan Hidraulik Beton Porous Menggunakan Bahan Tambah Abu Batu
}

(Mechanichal and Hydraulic Properties Evaluation of Pervious Concretes Utilizing Stone Fly Ash)

\author{
AGUNG SETIAWAN, MOCHAMAD TEGUH
}

\begin{abstract}
ABSTRAK
Penggunaan beton konvensional sebagai lapis permukaan bersifat kedap, berdampak potensi genangan air dan banjir. Salah satu upaya mereduksi limpasan permukaan dan meningkatkan resapan air hujan dengan menggunakan beton porous. Penelitian bertujuan mengkaji dan evaluasi kinerja sifat mekanik dan hidraulik beton porous dengan bahan tambah abu batu sisa penggergajian kerajinan batu Gunung Merapi. Dalam penelitian percobaan laboratorium ini digunakan 4 (empat) variasi komposisi campuran semen, abu batu, agregat, dan faktor air semen sebagai berikut: 1:1:5, 1:1:6, 1:1:7 dan 1:1:8 serta faktor air semen 0,4. Pengujian benda uji mengikuti standar dan prosedur ACI 522R-10. Hasil penelitian menunjukkan beton porous dengan ukuran agregat $1-2 \mathrm{~cm}$ dan abu batu meningkatkan kuat tekan tetapi daya lolos air menurun. Kuat tekan beton porous tertinggi menggunakan ukuran agregat kecil $(1-2 \mathrm{~cm})$ dengan abu batu 7,47 MPa. dengan infiltrasi $0,28 \mathrm{~cm} / \mathrm{s}$ dan permeabilitas $2,81 \mathrm{~cm} / \mathrm{s}$. Peningkatan kuat tekan menggunakan abu batu ukuran agregat 1-2 cm sebesar 40,83\% dan ukuran agregat 2-3 cm sebesar 62,30\%.
\end{abstract}

Kata kunci: Beton Porous, Abu Batu, Kuat Tekan, Infiltrasi, Permeabilitas.

\section{ABSTRACT}

The use of conventional concrete as a surface layer is impermeable, impacting the potential for puddles and flooding. One of the efforts to reduce surface runoff and increase rainwater infiltration can be using porous concrete. The aim of the study was to evaluate the mechanical and hydraulic properties of porous concrete with added fly ash from sawing stone crafts at Mount Merapi. In this experimental study, the following 4 (four) compositions of cement, aggregate, fly ash, and water-cement ratio were used: 1:1:5, 1:1:6, 1:1:7 and 1:1:8 as well as the following $w / c$ 0,4. Testing of the specimens followed the standards and procedures of ACI 522R-10. The results showed that porous concrete with an aggregate size of 1-2 cm an fly ash increased the compressive strength but decreased hydraulic conductivity. The highest compressive strength of porous concrete uses small aggregate size $(1-2 \mathrm{~cm})$ with fly ash $7.47 \mathrm{MPa}$., infiltration rate $0.28 \mathrm{~cm} / \mathrm{s}$ and permeability $2.81 \mathrm{~cm} / \mathrm{s}$. The increase in compressive strength using fly ash with an aggregate size of $1-2 \mathrm{~cm}$ is $40.83 \%$ and an aggregate size of $2-3 \mathrm{~cm}$ is $62.30 \%$.

Keywords: Pervious Concrete, Stone Fly Ash, Compressive Strength, Infiltration, Permeability.

\section{PENDAHULUAN}

Pertumbuhan ekonomi dan penduduk menuntut ketersediaan infrastruktur dan fasilitas pelayanan umum. Fasilitas umum seperti jalan lingkungan, trotoar dan fasilitas ruang terbuka sebagian besar menggunakan material konstruksi kedap air. Material konstruksi kedap air berdampak lahan yang semula mampu meresapkan air hujan menjadi kedap air. Kondisi ini tentu tidak menguntungkan, karena limpasan permukaan tersebut berpotensi meningkatkan debit banjir dan berkurangnya cadangan air tanah. Metode pengendalian limpasan permukaan menggunakan vegetatif, mekanik, maupun konstruktif, serta memanfaatkan lapisan akuifer sebagai sarana penyimpan cadangan air. Beton porous dikenal sebagai beton berpori adalah beton yang mempunyai kemampuan meloloskan air. 
American Concrete Institute (ACI, 2010), menyatakan komposisi beton porous tersusun dari semen, agregat kasar, sedikit atau tanpa agregat halus, bahan tambah dan air. Beton porous cenderung memiliki nilai slump yang mendekati nol. Kombinasi campuran material tersebut menghasilkan beton porous dengan pori-pori yang saling terhubung dengan agregat berukuran antara 2 sampai $8 \mathrm{~mm}$, sehingga memungkinkan air lewat dengan mudah. Kuat tekan beton porous berada direntang 2,8 hingga $28 \mathrm{MPa}$. Laju drainase perkerasan beton tembus air bervariasi sesuai ukuran agregat dan kepadatan campuran, umumnya dalam kisaran 2 sampai 18 $\mathrm{gal} / \mathrm{min} / \mathrm{ft}^{2}\left(81 \mathrm{sampai} 730 \mathrm{l} / \mathrm{min} / \mathrm{m}^{2}\right.$ ) atau 192 sampai $1.724 \mathrm{in} / \mathrm{j}(0,14$ hingga $1,22 \mathrm{~cm} / \mathrm{s})$.

Material agregat yang digunakan dalam campuran beton porous sama dengan beton konvensional, kecuali agregat halus yang kadang digunakan atau tidak. Kuantitas, proporsi dan teknik pencampuran mempengaruhi karakteristik beton porous khususnya kuat tekan dan struktur pori. Agregat kasar yang digunakan biasanya berukuran hingga $20 \mathrm{~mm}$. Ukuran agregat yang digunakan $6 \mathrm{~mm}$ sampai $20 \mathrm{~mm}$, akan tetapi yang sering digunakan ukuran $10 \mathrm{~mm}$ seragam. Bentuk agregat bisa bulat seperti kerikil atau batu pecah (Selvaraj \& Amirthavarshini, 2016).

Penelitian beton porous berkembang dengan melakukan variasi komposisi campuran, variasi bentuk dan ukuran agregat dan bahan tambah. Beberapa cara meningkatkan kuat tekan beton antara lain dengan menambahkan aditif mineral silicafume atau abu terbang dan bahan kimia. Bahan pengganti sebagian semen berupa mineral tambahan, material pozolan buatan seperti slag dan fly ash atau material pozolan alam. Material pozolan alam salah satunya adalah volcanic tuff.

Pada penelitian beton porous ini dilakukan dengan memberi bahan tambah abu batu sisa penggergajian kerajinan batuan Gunung Merapi, untuk mengetahui pengaruhnya terhadap kuat tekan, infiltrasi dan permeabilitas. Abu batu limbah penggergajian kerajinan batu mempunyai ukuran butiran yang lembut dan merata. Abu batu juga mempunyai tekstur tajam. Karakteristik abu batu ini diharapkan bermanfaat sebagai filler dan memperkuat ikatan. Abu batu ini dapat difungsikan sebagai pengisi dalam adukan beton untuk pembuatan batako (Winarno,
2017). Bahan pengisi abu batu dalam adukan batako menjadikan batako menjadi lebih padat sehingga kuat tekan meningkat.

Kuat tekan beton berpori mengalami penurunan seiring bertambah besarnya ukuran agregat $1-2 \mathrm{~cm}$ dan $2-3 \mathrm{~cm}$. Ukuran agregat tidak mempengaruhi nilai permeabilitas dikarenakan hasil yang diperoleh hampir sama (Pratomo, dkk., 2016)

Peiliang, dkk. (2020) mengembangkan penelitian beton porous untuk mendapatkan sifat mekanik kuat tekan tinggi. Metode penelitian dengan menggabungkan rancangan campuran umum dan rancangan campuran penggunaan pasta semen kecil, peningkatan keseragaman ukuran agregat dan perbaikan kualitas ikatan antar agregat. Karakteristik mekanik (kuat tekan) dari beton porous tergantung dari 3 (tiga) faktor yaitu: pasta semen, agregat dan karakteristik ikatan antara pasta semen dengan agregat. Agregat yang mempunyai ukuran lebih kecil $3 \mathrm{~mm}$ lebih besar kuat tekannya karena pasta semen lebih cukup menyelimuti permukaan agregat. Kualitas pasta semen bermutu tinggi mampu mengikat agregat yang kuat. Agregat yang digunakan beragam ukuran mulai dari 1,18 $2,38 \mathrm{~mm}, 2,36-5 \mathrm{~mm}$ dan $5-10 \mathrm{~mm}$.

Faktor air semen yang digunakan lebih besar dari 0,45 mengakibatkan pasta semen menjadi terlalu cair. Pasta semen akan terlepas dari agregat mengalir ke bawah sampel. Kondisi ini menyebabkan pengendapan pasta semen di dasar. Faktor air semen yang lebih kecil dari 0,45 mengakibatkan pasta tidak akan merata untuk melapisi permukaan agregat. Optimalisasi faktor air semen memungkinkan pasta semen melapisi permukaan agregat secara merata (Ginting, 2015).

\section{METODE PENELITIAN}

Penelitian ini dilakukan dengan metode percobaan secara langsung yaitu pembuatan benda uji beton porous dan pengujian di laboratorium. Benda uji beton porous dibuat dengan berbagai variasi perbandingan campuran semen dengan agregat. Campuran beton porous selain tanpa bahan tambah juga dengan bahan tambah abu batu, faktor air semen (fas) ditetapkan 0,4. Semua benda uji dilakukan test kuat tekan (sifat mekanik) dan hidraulik beton porous. 


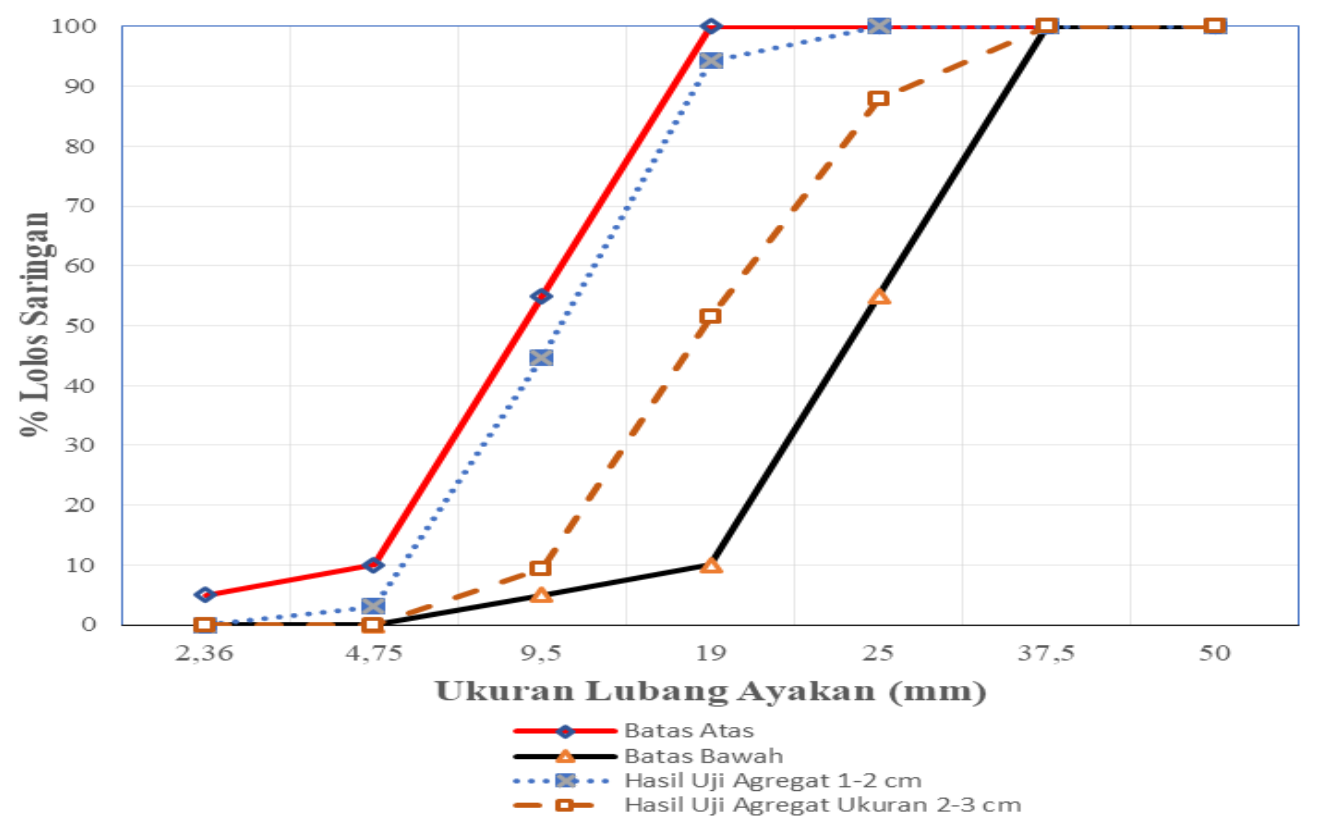

GAMBAR 1. Grafik Gradasi Seragam Agregat Kasar Ukuran 1-2 cm dan 2-3 cm

\section{Material}

Semen yang digunakan pada campuran beton porous adalah Portland Composite Cement (PCC), Semen Portland tersebut merupakan Blended Cement atau semen campur mengacu SNI 15-7064-2004.

Agregat kasar, yaitu batu hasil produksi stone crusher berupa batu pecah (split) ukuran 1-2 $\mathrm{cm}$ dan 2-3 cm, berasal dari Kali Jali, Purworejo, Jawa Tengah. Beton porous dibuat menggunakan agregat kasar ukuran 1-2 cm dan 2-3 $\mathrm{cm}$ dengan gradasi seragam. Hasil gradasi seragam seperti terlihat pada Gambar 1.

Agregat kasar harus mempunyai kualitas bagus. Agregat kasar yang digunakan mempunyai nilai keausan sebagai berikut agregat ukuran 1-2 mm sebesar 18,64\% dan agregat 2-3 mm sebesar 19,97\%.
Air, persyaratan kualitas air mengacu standar beton konvensional SNI 03-6871-2002. Air berasal dari Laboratorium Teknik Sipil Universitas Muhammadiyah Purworejo.

Bahan tambah, abu batu merupakan sisa penggergajian kerajinan batu yang banyak terdapat di sekitar Kecamatan Cangkringan, Kecamatan Turi, atau Kecamatan Muntilan. Abu batu berwarna abu-abu ukuran butirnya halus menyerupai debu. Ukuran butirannya merata sehingga tidak diperlukan proses pengayakan.

\section{Pembuatan Benda Uji}

Rancangan benda uji dibuat dengan mempertimbangkan workability tertentu. ACI (2010) mengisyaratkan komposisi campuran beton porous seperti dalam Tabel 1 .

TABEL 1. Komposisi Campuran Beton Porous

\begin{tabular}{|c|c|}
\hline Material & Proporsi $\left(\mathrm{kg} / \mathrm{m}^{3}\right)$ \\
\hline Semen & $270-415$ \\
\hline Agregat Kasar & $1.190-1.480$ \\
\hline Faktor Air Semen & $0,27-0,34$ \\
\hline Semen : Agregat & $1: 4$ sampai dengan 4,5 \\
\hline Ratio Agregat halus & $0-1: 1$ \\
\hline
\end{tabular}


Benda uji yang digunakan untuk kuat tekan berupa cetakan silinder dengan ukuran 150 $\mathrm{mm} \times 300 \mathrm{~mm}$. Benda uji untuk pengujian infiltrasi dan permeabilitas dicetak dalam pipa Polivynil Chloride (PVC) diameter 6 inch tinggi $20 \mathrm{~cm}$. Kebutuhan material campuran beton porous menggunakan agregat $1-2 \mathrm{~cm}$ dan 2-3 cm yang dapat dilihat pada Tabel 3 dan Tabel 4.

\section{Pengujian Infiltrasi dan Permeabilitas}

\section{Infiltrasi}

Struktur beton porous mempunyai rongga atau pori udara yang dapat meloloskan air. Air yang jatuh di permukaan akan meresap ke dalam beton porous. Infiltrasi adalah aliran air dari permukaan beton porous ke dalam beton porous. Pengukuran dan nilai infiltrasi beton porous dilakukan merujuk ASTM C1701 (Nassiri, dkk., 2017) menggunakan persamaan sebagai berikut:

$$
I=\frac{4 V}{D^{2} \pi t}
$$

dengan

$$
\begin{array}{ll}
\text { I } & =\text { Infiltrasi }(\mathrm{cm} / \mathrm{s}) \\
\mathrm{V} & =\text { Volume air }\left(\mathrm{cm}^{3}\right) \\
\mathrm{D} & =\text { Diameter sampel }(\mathrm{cm}) \\
\mathrm{t} & =\text { Waktu air surut }(\text { detik) }
\end{array}
$$

Pengujian infiltrasi dilakukan dengan cara menuangkan volume air tertentu ke permukaan sampel beton porous dan diukur waktunya (Gambar 2).

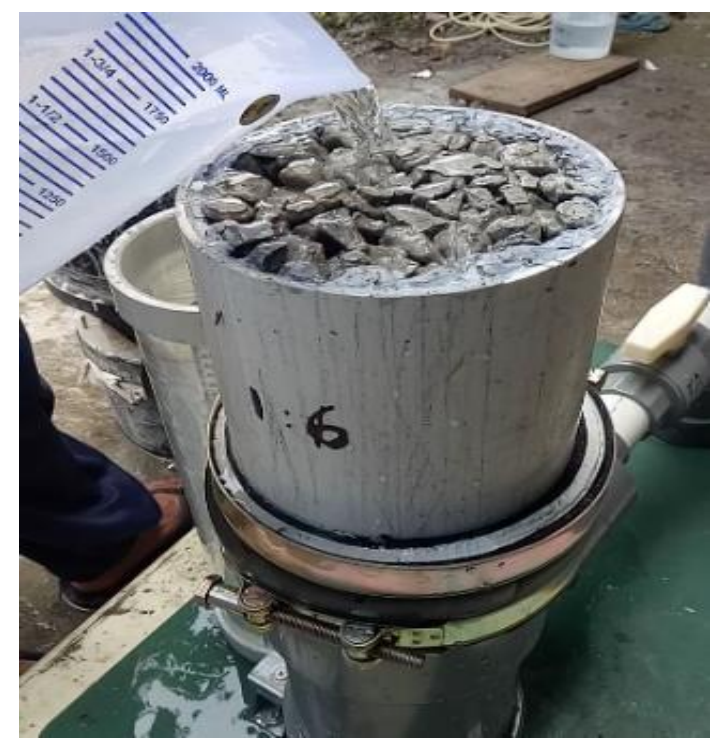

GAMBAR 2. Pengujian Infiltrasi Beton Porous

\section{Permeabilitas}

Permeabilitas beton porous adalah kemampuan meloloskan air dalam kondisi jenuh. Pengukuran permeabilitas beton porous menggunakan metode falling head permeability (Ajamu, dkk., 2012). Persamaan permeabilitas dengan metode falling head adalah:

$$
K=2,303 \frac{\alpha L}{A \Delta t} \log \left(\frac{h_{0}}{h_{1}}\right)
$$

dengan

$\mathrm{K}=$ Permeabilitas $(\mathrm{cm} / \mathrm{s})$

$\mathrm{L} \quad=$ tebal benda uji $(\mathrm{cm})$

$\alpha \quad=$ luas tabung ukur $\left(\mathrm{cm}^{2}\right)$

A $\quad=$ luas silinder benda uji $\left(\mathrm{cm}^{2}\right)$

$\mathrm{h}_{0} \quad=$ tinggi air awal tabung ukur $(\mathrm{cm})$

$\mathrm{h}_{1} \quad=$ tinggi air akhir tabung ukur $(\mathrm{cm})$

$\Delta \mathrm{t} \quad=$ interval waktu pengukuran (detik)

Pengujian infiltrasi dan permeabilitas dilakukan untuk mendapatkan kinerja beton porous dalam meloloskan air. Peralatan yang digunakan dapat dilihat pada Gambar 3 dan 4.

Pengujian permeabilitas Metode Falling Head dilakukan dengan tahapan sebagai berikut:

a. Benda uji beton porous diletakkan di bawah tabung acrylic terikat dengan lapis karet agar tidak terjadi kebocoran.

b. Tabung acrylic diisi air sampai ketinggian tertentu (ho) dan benda uji kondisi jenuh.

c. Stop kran air dibuka hingga terjadi beda tinggi kurang lebih $150 \mathrm{~mm}$, stop kran air ditutup, waktu penurunan air dicatat.

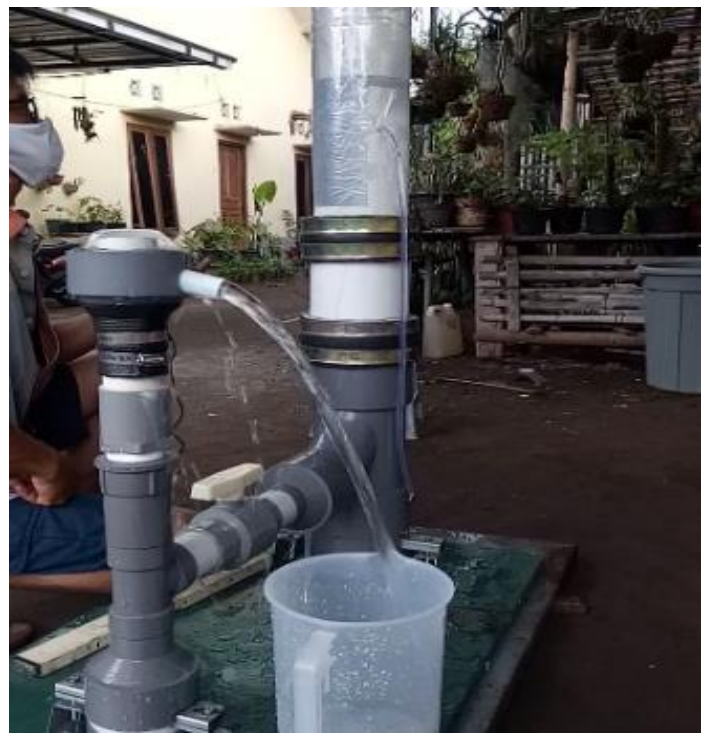

Gambar 3. Pengujian Permeabilitas Beton Porous 


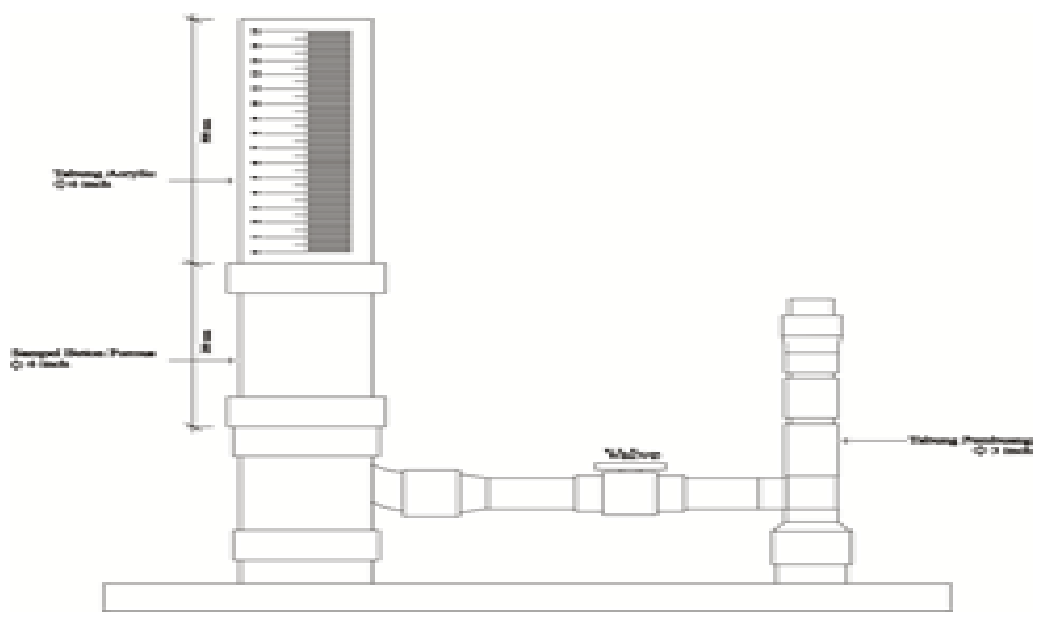

GAMbar 4. Alat Pengujian Permeabilitas

HASIL DAN PEMBAHASAN

Pengujian kandungan kimia abu batu sisa penggergajian kerajinan batu Gunung Merapi dilakukan di Laboratorium Penelitian dan Pengujian Terpadu (LPPT) UGM. Kandungan kimia abu batu sisa penggergajian kerajinan batu Gunung Merapi, berdasarkan hasil pengujian beberapa parameter disajikan pada Tabel 2.

\section{Hasil Pengujian Kuat Tekan}

Pengujian kuat tekan beton porous dilakukan pada umur 28 hari tanpa dan dengan bahan pengisi abu batu sisa penggergajian kerajinan batuan pada berbagai variasi komposisi campuran, seperti terlihat pada Tabel 5.

TABel 2. Kandungan Kimia Abu Batu Sisa Penggergajian Batuan Gunung Merapi

\begin{tabular}{ccc}
\hline Parameter & Satuan & Hasil \\
\hline Si (Silika) & $\mathrm{mg} / \mathrm{kg}$ & $1.320,76$ \\
$\mathrm{Ca}$ (Calsium) & $\%$ & 1,98 \\
$\mathrm{Mg}$ (Magnesium) & $\mathrm{mg} / \mathrm{kg}$ & $2.528,05$ \\
$\mathrm{Fe}$ (Besi) & $\%$ & 2,91 \\
\hline
\end{tabular}

TABEL 3. Kebutuhan Material Beton Borous Tanpa Abu Batu

\begin{tabular}{cccc}
\hline $\begin{array}{c}\text { Komposisi Campuran } \\
\text { Semen : Agregat }\end{array}$ & $\begin{array}{c}\text { Semen } \\
(\text { gram) }\end{array}$ & $\begin{array}{c}\text { Agregat } \\
(\text { gram) }\end{array}$ & $\begin{array}{c}\text { Air } \\
(\text { gram) }\end{array}$ \\
\hline $1: 5$ & 1.500 & 7.500 & 600 \\
$1: 6$ & 1.250 & 7.500 & 500 \\
$1: 7$ & $1.071,43$ & 7.500 & 428,57 \\
$1: 8$ & 937,5 & 7.500 & 375 \\
\hline
\end{tabular}

TABel 4. Kebutuhan Material Beton Porous Dengan Abu Batu

\begin{tabular}{ccccc}
\hline $\begin{array}{c}\text { Komposisi Campuran } \\
\text { Semen : Agregat }\end{array}$ & $\begin{array}{c}\text { Semen } \\
(\text { gram) }\end{array}$ & $\begin{array}{c}\text { Agregat } \\
\text { (gram) }\end{array}$ & $\begin{array}{c}\text { Air } \\
(\text { gram) }\end{array}$ & $\begin{array}{c}\text { Abu batu } \\
\text { (gram) }\end{array}$ \\
\hline $1: 1: 5$ & 1.500 & 7.500 & 600 & 1.500 \\
$1: 1: 6$ & 1.250 & 7.500 & 500 & 1.250 \\
$1: 1: 7$ & $1.071,43$ & 7.500 & 428,57 & $1.071,43$ \\
$1: 1: 8$ & 937,5 & 7.500 & 375 & 937,5 \\
\hline
\end{tabular}


TABEL 5. Kuat Tekan Beton Porous Tanpa Abu Batu Agregat Ukuran 1-2 cm dan 2-3 cm.

\begin{tabular}{ccccc}
\hline & \multicolumn{2}{c}{ Agregat 1-2 cm } & \multicolumn{2}{c}{ Agregat 2-3 cm } \\
\cline { 2 - 6 } & Tanpa Abu Batu & Dengan Abu Batu & Tanpa Abu Batu & Dengan Abu Batu \\
\hline Komposisi & \multicolumn{2}{c}{ Kuat Tekan } & \multicolumn{3}{c}{ Kuat Tekan } \\
(MPa)
\end{tabular}

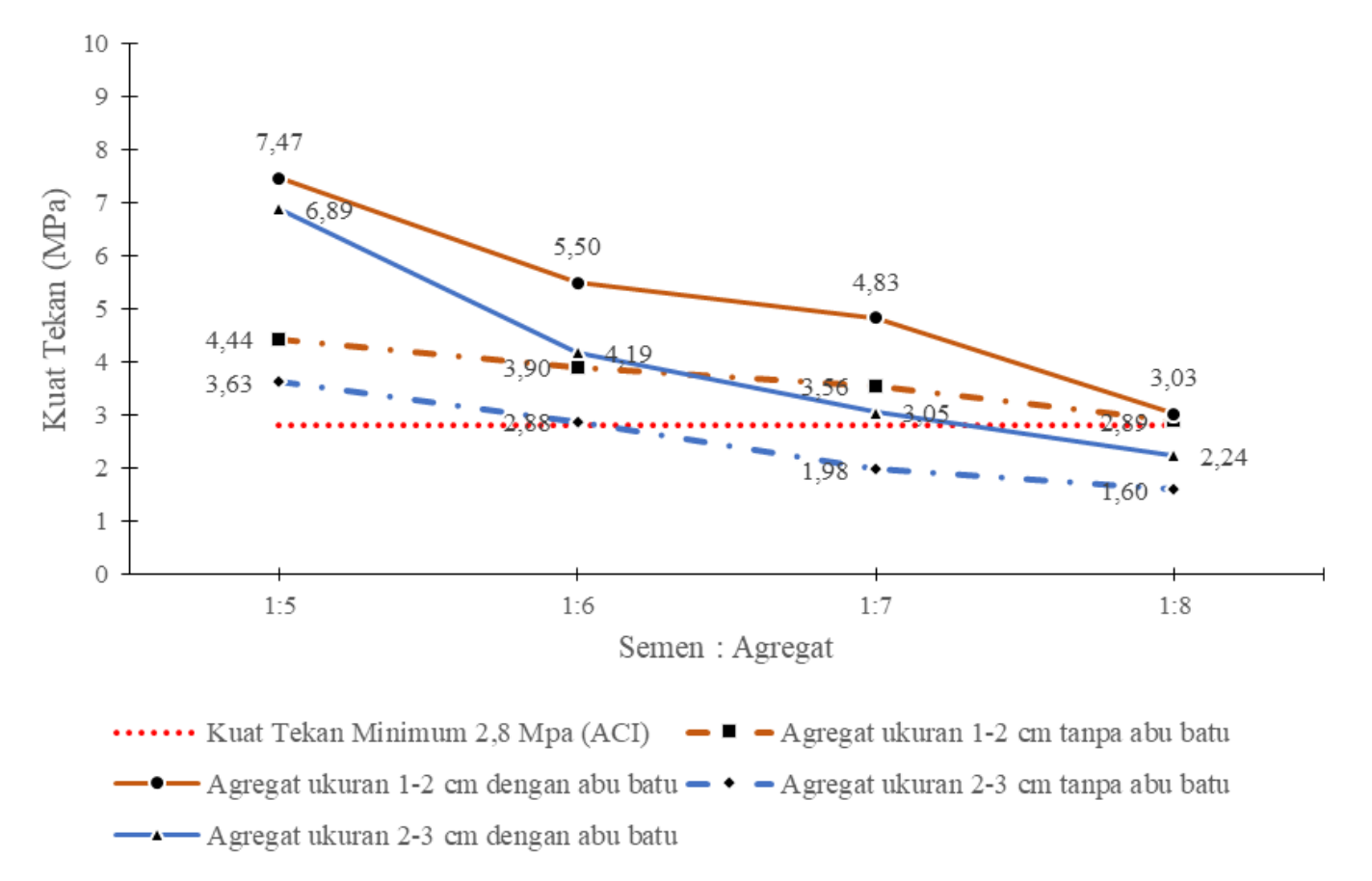

Gambar 5. Kuat Tekan Beton Porous Variasi Campuran Tanpa dan Dengan Abu Batu

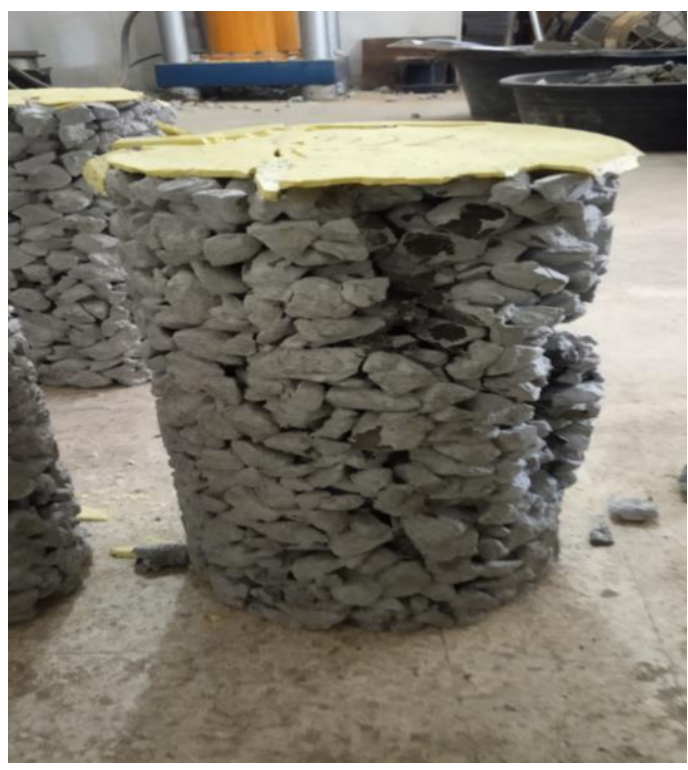

GAMBAR 6. Kerusakan Beton Porous Tanpa Abu Batu

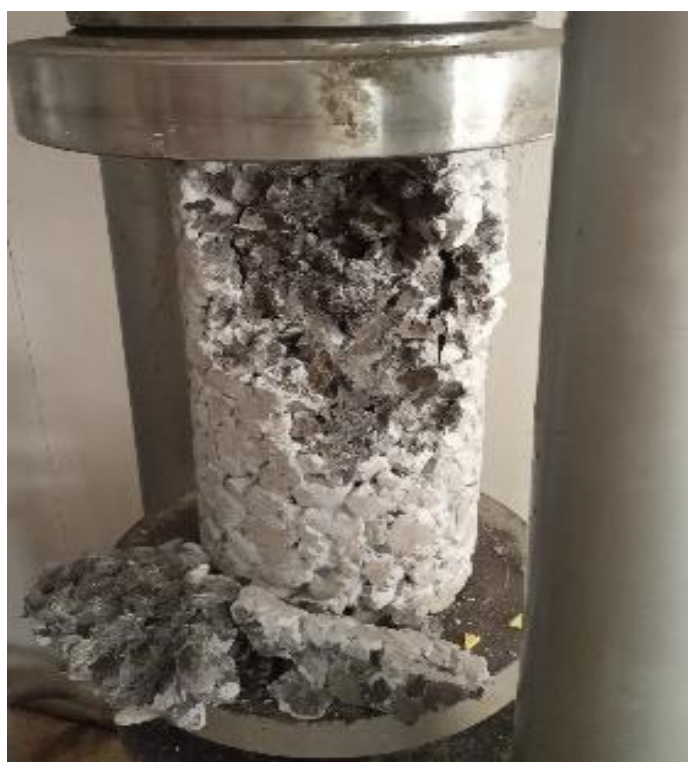

GAmBAR 7. Kerusakan Beton Porous Dengan Abu Batu 
Perbandingan campuran semen dengan agregat yang semakin besar akan menurunkan kuat tekan beton porous. Kuat tekan beton porous menggunakan bahan tambah abu batu menunjukkan peningkatan. Perbandingan semen dengan agregat semakin besar akan menyebabkan pasta semen yang mengikat permukaan butiran agregat semakin berkurang. Kondisi ini berakibat kekuatan ikatan antar butiran agregat menjadi berkurang. Pasta semen dan abu batu yang terlalu banyak mengakibatkan turun ke bawah, akan membentuk sumbatan aliran air.

\section{Hasil Pengujian Infiltrasi}

Nilai infiltrasi beton porous tertinggi didapat pada perbandingan komposisi campuran semen agregat 1:8 tanpa abu batu. Nilai infiltrasi beton porous menggunakan agregat ukuran 2-3 $\mathrm{cm}$ tanpa abu batu tertinggi sebesar $2,66 \mathrm{~cm} / \mathrm{s}$, agregat ukuran 1-2 tertinggi sebesar $0,68 \mathrm{~cm} / \mathrm{s}$. Hasil pengujian ditampilkan pada Tabel 6 dan Gambar 8.

TABEL 6. Hasil Uji Infiltrasi Beton Porous

\begin{tabular}{ccccc}
\hline & \multicolumn{2}{c}{ Agregat 1-2 cm } & \multicolumn{2}{c}{ Agregat 2-3 cm } \\
\cline { 2 - 6 } & Tanpa abu batu Dengan abu batu & Tanpa abu batu & Dengan abu batu \\
\hline Komposisi & \multicolumn{3}{c}{ Infiltrasi } & \multicolumn{3}{c}{ Infiltrasi } \\
Campuran & \multicolumn{2}{c}{$(\mathbf{c m} / \mathbf{s})$} & & \\
\hline $1: 5$ & 0,44 & 0,28 & 1,65 & 1,03 \\
$1: 6$ & 0,51 & 0,30 & 1,97 & 1,23 \\
$1: 7$ & 0,56 & 0,34 & 2,30 & 2,02 \\
$1: 8$ & 0,68 & 0,35 & 2,66 & 2,16 \\
\hline
\end{tabular}

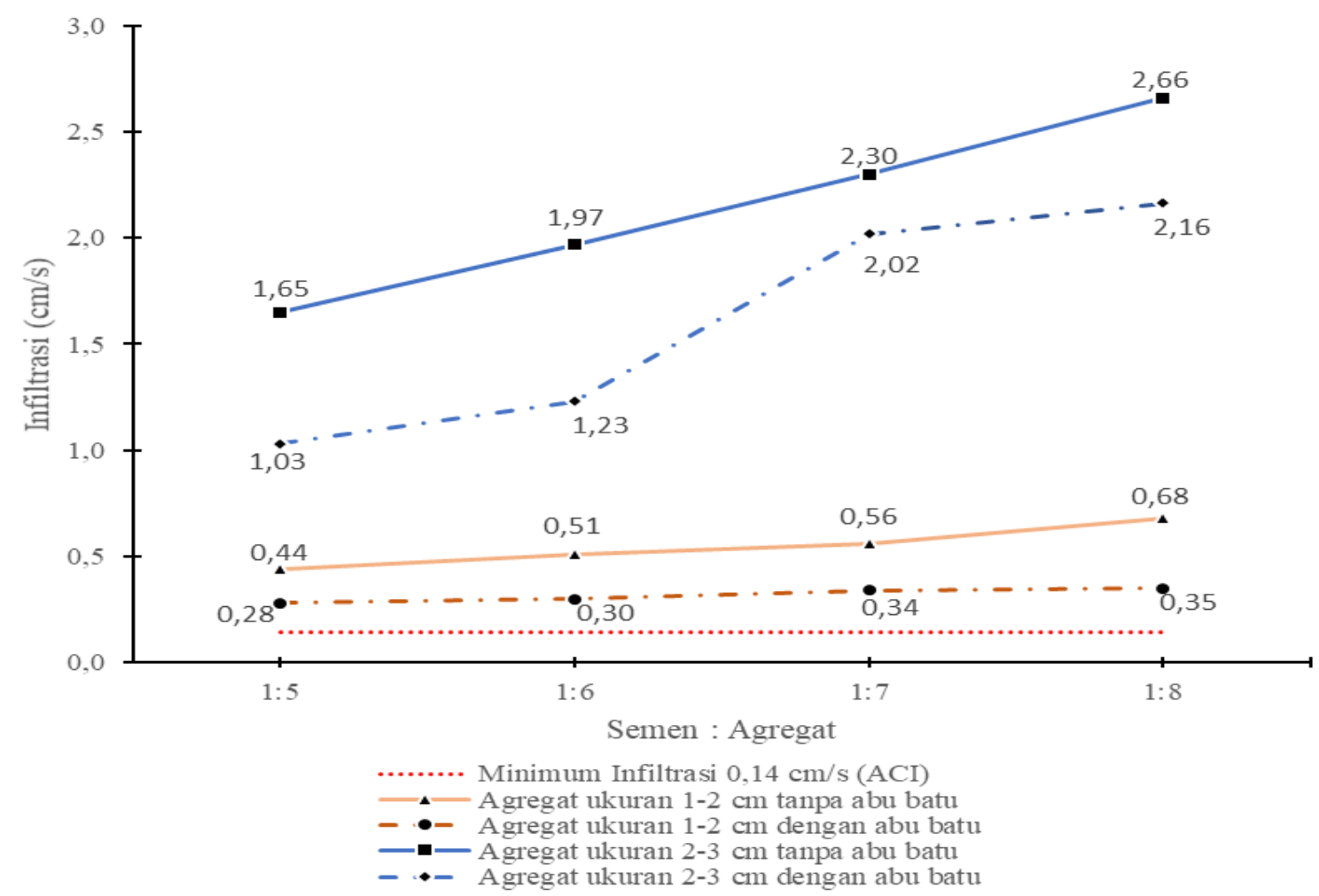

GAmbar 8. Infiltrasi Beton Porous Variasi Komposisi Campuran Tanpa dan Dengan Abu Batu 
TABel 7. Hasil Uji Permeabilitas Beton Porous Tanpa Abu Batu Agregat Ukuran 1-2 cm dan 2-3 cm

\begin{tabular}{|c|c|c|c|c|}
\hline & \multicolumn{2}{|c|}{ Agregat $1-2 \mathrm{~cm}$} & \multicolumn{2}{|c|}{ Agregat $2-3 \mathrm{~cm}$} \\
\hline & Tanpa abu batu & Dengan abu batu & Tanpa abu batu & Dengan abu batu \\
\hline $\begin{array}{l}\text { Komposisi } \\
\text { Campuran }\end{array}$ & \multicolumn{2}{|c|}{$\begin{array}{c}\text { Permeabilitas } \\
(\mathrm{cm} / \mathrm{s})\end{array}$} & \multicolumn{2}{|c|}{$\begin{array}{c}\text { Permeabilitas } \\
(\mathrm{cm} / \mathrm{s})\end{array}$} \\
\hline $1: 5$ & 2,81 & 0,84 & 3,37 & 1,13 \\
\hline $1: 6$ & 3,62 & 1,11 & 3,66 & 1,26 \\
\hline $1: 7$ & 3,88 & 1,80 & 4,53 & 3,47 \\
\hline $1: 8$ & 4,11 & 1,96 & 4,76 & 3,96 \\
\hline
\end{tabular}

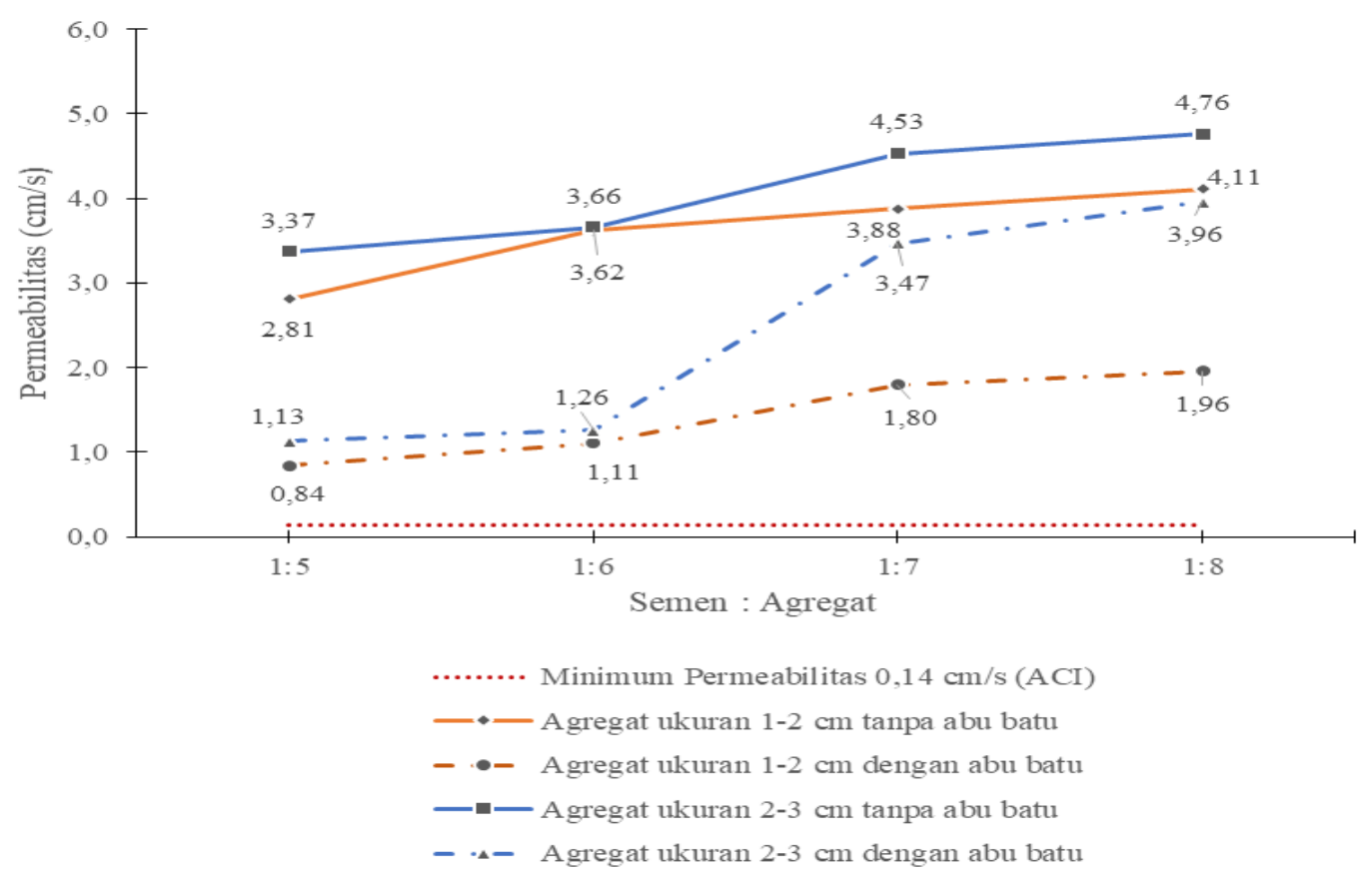

GAMbar 9. Permeabilitas Beton Porous Variasi Campuran Tanpa dan Dengan Abu Batu

\section{Hasil Pengujian Permeabilitas}

Pengujian permeabilitas dilakukan pada umur 14 hari. Pada saat tersebut benda uji mempunyai daya lekat yang kuat. Hasil pengujian permeabilitas beton porous tanpa dan dengan abu batu ditunjukkan pada Tabel 7 dan Gambar 9.

Nilai permeabilitas beton porous tertinggi didapat pada perbandingan komposisi campuran semen agregat 1:8 tanpa abu batu. Nilai permeabilitas beton porous menggunakan agregat ukuran 2-3 cm tanpa abu batu tertinggi sebesar $4,76 \mathrm{~cm} / \mathrm{s}$, agregat ukuran $1-2 \mathrm{~cm}$ tertinggi sebesar $4,11 \mathrm{~cm} / \mathrm{s}$.

Perbandingan campuran semen dengan agregat yang semakin besar, akan menurunkan kuat tekan dan meningkatkan laju infiltrasi dan permeabilitas. Kuat tekan porous tertinggi didapat pada campuran yang menggunakan agregat ukuran 1-2 cm dengan abu batu. Kuat tekan cenderung menurun pada beton porous yang menggunakan agregat ukuran $2-3 \mathrm{~cm}$. Pasta semen pada beton porous yang menggunakan agregat ukuran 2-3 cm semakin sedikit menyelimuti permukaan agregat, mengakibatkan ikatan antar agregat berkurang dan semakin berongga atau porous (Kurniadi \& Himawan, 2019). Kinerja beton porous agregat ukuran 1-2 cm menggunakan abu batu nilai kuat tekan meningkat 40,83\% lebih besar daripada tanpa abu batu. Kinerja beton porous agregat ukuran 2-3 cm menggunakan abu batu nilai kuat tekan meningkat $62,30 \%$ lebih besar daripada agregat ukuran 1-2 cm batu. Kinerja parameter hidraulik infiltrasi dan permeabilitas beton porous menurun pada campuran yang menggunakan abu batu. Abu batu mempunyai 
sifat menyerap air sehingga mengurangi kecenderungan bleeding beton segar. Peningkatan kuat tekan dan penurunan kinerja hidraulik beton porous dengan abu batu menunjukkan abu batu bereaksi dengan semen sebagai bahan ikat dan mengisi rongga. Bahan tambah abu batu sisa kerajinan batuan vulkanik Gunung Merapi mampu meningkatkan kuat tekan beton porous akan tetapi menurunkan kemampuan meloloskan air.

\section{KESIMPULAN}

Dari hasil pengujian dan analisa dapat diambil kesimpulan bahwa penggunaan bahan tambah abu batu mampu meningkatkan kuat tekan beton porous, tetapi menurunkan sifat hidraulik yaitu infiltrasi dan permeabilitas. Perbandingan agregat dengan semen beton porous semakin besar menurunkan kuat tekan dan meningkatkan kemampuan loloskan air.

Kuat tekan beton porous menggunakan agregat ukuran 1-2 cm dengan bahan tambah abu batu terbesar yaitu 7,47 MPa komposisi campuran 1:1:5. Karakteristik hidraulik infiltrasi 0,28 $\mathrm{cm} /$ detik dan permeabilitas $0,84 \mathrm{~cm} /$ detik. Hasil kuat tekan, infiltrasi dan permeabilitas masih berada rentang angka yang diisyaratkan dalam ACI 522R-10.

\section{DAFTAR PUSTAKA}

Ajamu, S. O., Jimoh, A. A., \& Oluremi, J. R. (2012). Evaluation of structural performance of pervious concrete in construction. International Journal of Engineering and Technology, 2(5), 829836.

American Concrete Institute (ACI). (2010). Report on Pervious Concrete 522R-10. Michigan, United State: ACI Committee 522.

Ginting, A. (2015). Kuat tekan dan porositas beton porous dengan bahan pengisi styrofoam. Jurnal Teknik Sipil, 11(2), 76-168.

https://doi.org/10.28932/jts.v11i2.1404

Kurniadi, E., \& Himawan, L. (2019). Kajian Kuat Tekan dan Infiltrasi Pada Beton Non Pasir. Jurnal Riset Rekayasa Sipil,
2(2), 72-78. https://doi.org/10.20961/jrrs.v2i2.28632

Nassiri, S., Rangelov, M., \& Chen, Z. (2017). Preliminary Study to Develop Standard Acceptance Tests for Pervious Concrete. Washington: Department of Civil and Enviromental Engineering.

Peiliang, S., Jian-Xin, L., Haibing, Z., Songhui, L., \& Chi Sun, P. (2020). Conceptual design and performance evaluation of high strength pervious. Construction and Building Materials. doi:https://doi.org/10.1016/j.conbuildma t.2020.121342

Pratomo, E. P., Setyawan, A., \& Djumari. (2016). Pengaruh Gradasi Terhadap Porositas dan Kuat Tekon Beton Berpori. Surakarta: Matriks Teknik Sipil, Universitas Sebelas Maret.

Selvaraj, R., \& Amirthavarshini, M. (2016). Some aspects on pervious concrete. International Journal of Engineering and Applied Sciences (IJEAS), 3(1), 610.

Standar Nasional Indonesia. (2002). SNI 036871-2002. Cara uji kelulusan air untuk tanah berbutir kasar dengan tinggi tekan tetap. Jakarta.

Standar Nasional Indonesia. (2004). SNI 157064-2004. Semen Portland komposit. Jakarta.

Winarno, S. (2017). Comparative strength and cost of rice husk concrete block, The $5^{\mathrm{TH}}$ International Conference On Sustainable Built Enviroment, Banjarmasin.

PENULIS:

Agung Setiawan

Program Studi Teknik Sipil, Fakultas Teknik, Universitas Muhammadiyah Purworejo. Jalan K.H.A. Dahlan No. 3 \& 6, Purworejo.

Email: agungsetiawan@umpwr.ac.id

Mochamad Teguh

Program Studi Teknik Sipil, FTSP, Universitas Islam Indonesia. Jalan Kaliurang Km. 14,5, Sleman, Yogyakarta.

Email: m.teguh@uii.ac.id 